\title{
A prática da educação construtivista: entrevista com Fernando Sarti Ferreira
}

Entrevista por Gabriel Yukio Shinoda Oliveira e Pedro José de Carvalho Neto

Transcrição por Beatriz Gasques Favilla, Gabriel Yukio Shinoda Oliveira, Gabriele Maria Oliveira, Guilherme Oliveira Souza, Leticia Oliver Fernandes, Marina de Almeida Spinola, Matheus de Paula Silva, Pedro José de Carvalho Neto e Yan Fernando Pereira Catuaba

Revisão por Gabriel Yukio Shinoda Oliveira, Gabriele Maria Oliveira, Letícia Oliver Fernandes, Matheus de Paula Silva e Pedro José de Carvalho Neto

DOI: 10.11606/issn.2318-8855.v9i2p130-152 


\section{entrevista}

A prática da educação construtivista

Fernando Sarti Ferreira, assim como provavelmente muitas de nossas leitoras e leitores, identificava-se com as humanidades desde a época de colégio. Isso o levou a escolher, primeiramente, a graduação em Filosofia. Cursando-a na USP por três anos, de 2002 a 2005, incontáveis foram suas experiências por lá, que, por exemplo, o ensinaram a ler textos densos e complicados. No entanto, percebia em si um apreço muito grande às discussões históricas dentro da própria Filosofia, o que o fez se transferir para a História em 2006. Nesse percurso Fernando se tornou mestre e doutor em História Econômica pela mesma universidade, tendo como tema a Argentina do começo do século $X X$.

Tendo caído quase sem querer no mundo da educação, atualmente Fernando leciona em uma escola construtivista particular em São Paulo. Durante nossa conversa, apontou vantagens dessa forma de ensino, embora reconheça suas limitações e contradições socioeconômicas; falamos, ainda, sobre o ensino à distância em tempos de pandemia e a precarização do profissional da educação. Citando Fernando, o recado é claro: "a escola não vai salvar a sociedade, é a sociedade que tem que salvar a escola".

Boa leitura a todos e todas!

Revista Epígrafe: Queríamos saber um pouco do seu percurso, como foi a sua aproximação com Ciências Humanas, com a História. A gente viu que você começou o curso de Filosofia e depois foi para a História. Como que foi essa sua aproximação? Por que você decidiu fazer primeiro Filosofia e depois História?

Fernando Ferreira: Desde a época do colégio eu já tinha uma maior identificação com as humanidades. Eu pensei em fazer todas as humanas, na verdade. Aí eu acabei optando por Filosofia, na Universidade de São Paulo. Eu entrei na Filosofia com 


\section{entrevista}

Fernando Sarti Ferreira

dezessete para dezoito anos, meio sem saber o que ia encontrar, e aí tive vários momentos de crise sobre como era a Filosofia. Ao longo do meu percurso por lá, eu fui percebendo que o que me aproximava mais, o que me encantava mais, eram justamente discussões vinculadas à História. O curso de Filosofia tem aquela expectativa da leitura estrutural, e se você chega ali querendo discutir um pouquinho de contexto histórico, os professores já te cortam, já te falam “Não, não faça isso. Isso não serve de nada". E o que me chamava atenção, me empolgava mais, eram justamente esses cursos que, de alguma forma, dialogavam com a questão histórica, e eu não via muito mais a possibilidade de seguir ali na Filosofia. Eu fiz uns 3 anos de graduação por lá... Em crise, né? Com essa questão sempre batendo para mim, sempre me perturbando ali. Aí quando eu estava aí perto dos vinte e poucos, um momento mais de definição, que eu tinha que começar a definir mais a minha trajetória, aí eu peguei e falei “bom, ou agora vai ou racha”. E aí eu acabei me decidindo pela História. Eu acredito que eu não perdi tempo na Filosofia, eu acho que isso é muito importante para mim. Puts, eu aprendi... Eu considero que eu aprendi a ler no curso de Filosofia, né? Então para mim, assim, foi um tempo de maturação intelectual também muito importante. E, enfim, não me arrependo de ter feito essa trajetória.

Revista Epígrafe: E depois que você realizou essa transição para a História, como você descreveria sua vida durante a graduação? Você chegou a realizar projetos acadêmicos? Teve alguma ligação com a militância?

Fernando Ferreira: Olha, eu tive o privilégio de poder fazer uma graduação sem ter que trabalhar oito horas por dia e sem ter que pegar quatro horas de transporte público, como muitos colegas fizeram e como muita gente tem que fazer ainda. Foi 


\section{entrevista}

A prática da educação construtivista

algo um tanto quanto tranquilo desse ponto de vista.

Sobre as atividades que eu fiz, eu estive no PET [Programa de Educação Tutorial] por um tempo. Logo, acabei me envolvendo com grupos de estudos também, como o GMarx [Grupo de Estudos de História e Economia Política], no qual estou até hoje. E ali no GMarx sempre estive também organizando minicursos e participando de debates que a gente mantém há quase 10 anos. Mas também eu acho que, tão formativo quanto essas experiências para mim na graduação, sem dúvida alguma, foi o movimento estudantil. Compôs aí um momento fundamental na minha graduação.

A minha militância sempre se deu numa postura quase de questionamento das entidades burocráticas, do que você poderia pensar numa coisa mais próxima ao anarquismo ou autonomismo; nunca numa oposição ferrenha às entidades, mas sempre uma postura crítica às entidades, principalmente a uma certa disputa partidária que havia em torno delas, que de certa forma minava uma organização mais orgânica do movimento estudantil. Mas eu participei de duas importantes mobilizações durante a minha graduação, essa longa graduação de História e de Filosofia: a greve de 2002 e depois a ocupação da reitoria de 2007. Foram dois movimentos muito importantes na primeira década dos anos 2000 e que, enfim, foram muito importantes, assim como as brigas de morte com alguns companheiros [risos]. Na verdade, foi tudo muito formativo.

Revista Epígrafe: E, ainda na sua graduação, você tem algum professor ou alguma professora que você destacaria como sendo fundamental na sua formação, como alguém que realmente te ensinou alguma coisa ali que você levou para depois da sua vida como historiador, como professor? 


\section{entrevista}

Fernando Sarti Ferreira

Fernando Ferreira: Ah, na Filosofia, por exemplo, eu tenho muito marcado os cursos do Franklin Leopoldo e Silva e da professora Marilena Chauí; na História, o professor Wilson Barbosa Nascimento e meu professor, que é meu orientador, o Lincoln Secco; até hoje temos uma parceria nos grupos de estudo, mestrado e doutorado. Acho que são figuras bem marcantes na minha trajetória...

Revista Epígrafe: E você chegou a fazer a licenciatura?

Fernando Ferreira: Então, foi uma coisa [risos]... Eu não fiz a licenciatura, eu atuo de maneira ilegal [risos]. Mas isso é uma coisa que na escola privada, em algumas, isso acontece... Eu não fiz a licenciatura porque eu não pensava em dar aula, era uma coisa que não passava na minha cabeça. Eu tinha trabalhado com pesquisa, olhava um pouco para arquivo também com uma certa simpatia, e foi via cursinho popular que eu comecei a dar aula, participando do Cursinho da Psicologia. Ali no cursinho que eu comecei a pegar gosto por dar aula... Nesse mesmo momento eu entrei no mestrado e aí me apareceu uma oportunidade de entrar na escola onde eu estou, e aí eu acabei me acertando, já faz uns 10 anos que eu estou na Escola da Vila.

Revista Epígrafe: Você acha que de alguma forma não ter feito a licenciatura te fez falta como professor? Porque tem um debate muito grande sobre quem vai fazer licenciatura como uma segunda opção e quem vai porque realmente quer ser professor. Enfim, isso faz falta na sua carreira ou você já acha que não?

Fernando Ferreira: Eu acho que nessa altura não... A essa altura da vida, já com 12 anos dando aula, eu acho que não. Enfim, eu acredito, depois desse tempo de experiência de sala de aula, que o curso de licenciatura devia estar mais na mão do 


\section{entrevista}

A prática da educação construtivista

Departamento de História... É muito difícil, em alguns debates, quando fica aquela sobreposição da pedagogia com a História, da disciplina ou da pedagogia etc. Isso é um tanto complicado porque não tem didática sem o objeto de conhecimento... Você estabelece uma didática, você estabelece estratégias em função de um determinado objeto. É claro que se aprende para caramba com os pedagogos, mas tem um ponto do debate que é muito complicado de avançar com alguém que não é historiador, é muito complicado... Mas essa é, assim, uma fala completamente impressionista, eu não me sinto nem um pouco autorizado a discutir isso profundamente, até porque não fiz ali a licenciatura.

Revista Epígrafe: E você falou que você chegou a flertar com o arquivo, que era uma coisa que você gostava, e falou que professor também não foi sua primeira opção de cara. Você chegou a fazer estágio, trabalhar com alguma outra área possível do historiador e, se sim, o que acrescentou para sua vida hoje como professor ou mesmo como pesquisador?

Fernando Ferreira: Eu fiz muita pesquisa, por exemplo, para doutorandos quando era aluno de graduação. Você pegava lá alguém que estava no doutorado e precisava fazer algum levantamento em arquivo. Participei numas três, quatro pesquisas dessas e também trabalhei com arquivo de uma professora da ECA [Escola de Comunicação e Artes] um tempo, organizando os arquivos dela, os artigos dela. Eu peguei, na verdade, muito gosto pela pesquisa por causa dessas experiências que eu tive. No arquivo do Estado, eu trabalhei com fontes primárias, jornais antigos, etc. Tive um trabalho de pesquisa também sobre a história da indústria farmacêutica. Gostei muito do trabalho. Trabalhar com fontes primárias foi muito bacana, principalmente com a imprensa, é uma coisa que eu trabalho bastante no doutorado até hoje. Uma 


\section{entrevista}

Fernando Sarti Ferreira

das que mais marcou foi uma pesquisa com um cara que é professor da FAU hoje, Renato Cymbalista, ele fez uma pesquisa sobre a evolução da morte, do mercado da morte, em São Paulo, da transformação da passagem do enterro na Igreja para um cemitério público, e a mercantilização disso; foi um trabalho bem longo de pesquisa que eu fiz para ele, de jornais no século XX. E é uma coisa que você não tem muito na graduação, pelo menos na graduação na minha época você não tinha, era basicamente um curso de historiografia. Que eu me lembro alguns poucos professores faziam esse trabalho mais voltado à fonte primária; então foi uma experiência bem bacana, que eu acho que é uma lacuna na nossa graduação.

Revista Epígrafe: Bom, aproveitando que a maioria do nosso público é graduando, muitas vezes tem esse dilema na graduação de "como que eu vou fazer o mestrado e trabalhar ao mesmo tempo?". Como você fez para conciliar essas duas coisas? Você acha que é possível?

Fernando Ferreira: É possível, mas desgastante, extremamente desgastante. Eu tive a possibilidade de ter licença durante o mestrado, mas é extremamente desgastante. Eu estou vivendo pela primeira vez, agora, em 10 anos, um momento que eu só estou dando aula. Então, eu não sei direito como é que é... [risos] Eu fiquei nessa dupla jornada durante 10 anos, né? Se eu tivesse tido a oportunidade material de ter pelo menos deixado um tempo a escola para me dedicar à pesquisa, eu acho que eu teria feito isso, mas não houve possibilidade. No mestrado, eu ainda tive um pouco essa possibilidade de ter licença, mas no doutorado eu não tive, fiz ele inteiro trabalhando. É algo puxado e você dimensiona sua pesquisa nesse sentido, sua pesquisa será uma pesquisa dentro do tempo que você tem ali. Impossível não é; recomendável, não sei, depende de você. Acho que vale tentar. Agora, você vai falar o quê, numa situação 


\section{entrevista}

A prática da educação construtivista

que a gente está de crise econômica? Larga o emprego para fazer uma pós? Isso não existe na atual situação, com bolsas sendo cortadas - não é nem que não estão atualizando o valor das bolsas, estão cortando! As Ciências Humanas estão sendo perseguidas, então eu acho que vai haver uma transformação também na pósgraduação. E as pessoas vão ter que fazer essa pós-graduação sem bolsa e trabalhando; é uma loucura. A gente sabe que muitos professores acham que a gente nasceu num berço de ouro e pode se dedicar exclusivamente a isso, mas o cara tem que começar a aceitar isso, porque não dá, ou vai ter só gente filha de milionário fazendo pós-graduação. É complicado, mas eu acho que, se você tem essa vontade, e eu acho que, principalmente, se você consegue - "consegue" parece que até depende da pessoa, né? - e está trabalhando em um lugar legal e que te dá espaço para fazer, eu acho que você deve fazer sim. É o que eu falei, eu não vou parar de estudar, eu gosto para caramba. Mas, assim, é possível, mas é complicado.

Revista Epígrafe: Como se deu a escolha do seu tema e do seu orientador?

Fernando Ferreira: Olha, a Argentina surgiu para mim por causa do momento político daquele país. O movimento social argentino surgiu para mim quando eu estava com 18 anos e ocorreu a crise de 2001, que foi a última grande crise na Argentina, com uma mobilização popular enorme. Então isso me chamou bastante atenção. Por outro lado, quando estourou a crise argentina ficou mais barato ir para lá do que ir para Santos, entendeu? Então, eu consegui fazer uma viagem como universitário e pude conhecer bem Buenos Aires e, assim, nossa, que lugar maluco! A coisa da crise ainda estourando lá, e as mobilizações, etc... Então isso me atraiu um pouco, mas acho que essa coisa da escolha do tema é bem aleatório, posso te dizer. Eu acho que é bacana, dentro do possível, uma coisa que você goste, também. Porque muitas 


\section{entrevista}

Fernando Sarti Ferreira

vezes te aparece uma oportunidade de fazer pesquisa em cima de uma coisa que é conveniente, sei lá, tem um grupo de estudos, tem uma bolsa que te permite fazer isso. Às vezes, você vai porque você precisa da grana e você consegue se apaixonar pelo tema, gostar do tema. Outros momentos não são bem assim, acho que a forma como o tema cai no seu colo, às vezes é bem aleatória; às vezes pode ser bem burocrática também. Eu acho que não há problema nisso. O problema é você ficar fazendo uma coisa que você não quer, porque isso é o complicado.

No meu tempo de graduação, havia uma relação mais fluida com os professores, me parece, até por essa maior circulação política, parece que havia um contato maior entre professores e alunos. Isso é uma impressão que eu tenho. Enfim, acho que era nessa proximidade, de ir aproximando com o professor, você fazia matéria, encontrava em alguma atividade no prédio e ele estava ali e vocês iam conversando, e isso ia gerando essa aproximação.

Revista Epígrafe: E como sua vida acadêmica, sua pesquisa, se relacionam com seu trabalho em sala de aula? Como você coloca o tema de pesquisa em sala de aula?

Fernando Ferreira: Então, quando eu comecei a dar aulas, acabou virando uma enorme preocupação ser inteligível. Muita gente fala em uma contradição entre você estar no ensino básico e pesquisar. Para mim foi o contrário, na verdade. Me ajudou, pois ser compreendido e conseguir dialogar virou uma preocupação; isso para minha escrita foi muito bom.

Acho que durante a aula, quando você está ali com um texto que você quer discutir com os alunos, eu acho que isso acaba te estimulando a fazer novos tipos de perguntas, novas leituras. Isso acabou virando uma busca por ser entendido, de conseguir transpor certas discussões, certas questões de uma forma mais inteligível. 


\section{entrevista}

A prática da educação construtivista

Para isso colaborou muito trabalhar com educação básica e fazer pesquisa.

Revista Epígrafe: Diante do que você faz hoje, o que é ser professor para você?

Fernando Ferreira: Falar sobre ser professor é difícil, porque todo mundo espera que você venha com aquela frase falando da missão [risos], mas eu não acho que seja isso. Na verdade, eu não consigo dissociar a minha atuação como historiador, pesquisador e professor. Trabalhando na educação básica, na verdade, isso ajudou muito na minha pesquisa e na minha formação acadêmica. Porque ao trabalhar na educação básica eu tinha uma questão muito fundamental que era: "eu preciso ser compreendido", "eu preciso construir caminhos de compreensão entre mim e um público mais variado possível". Então, essa preocupação em ser claro, em ser, enfim, inteligível, e que veio com a minha atuação na educação básica, foi muito importante na minha formação como professor, e eu não dissocio, eu acho que são duas coisas bem sociáveis. Mas agora, do ponto de vista material, do ponto de vista concreto do que é ser professor hoje em dia, é muito complicado, é extremamente complicado, é aquela profissão que as pessoas dizem mais valorizar, mas é totalmente desvalorizada. Isso também ocorre na rede privada. Acho que de onde eu falo é um lugar bem privilegiado, com ótimas condições de trabalho perto do que existe na própria rede privada, porque o que predomina no ensino privado são pequenas escolas em que os professores que trabalham nelas têm que trabalhar em duas, três escolas; muitos são professores da rede pública e complementam renda no ensino privado. Pensando não só no meu caso específico, mas essa é uma categoria bem difícil. É muito frustrante, porque simplesmente as condições não são dadas. Mas enfim, por outro lado, eu não sei me ver fazendo outra coisa. Eu acho que tem muito essa carga da missão, é um discurso que muitos professores incorporam. 


\section{entrevista}

Fernando Sarti Ferreira

Revista Epígrafe: Você chegou a falar desse lugar privilegiado que você trabalha, numa escola construtivista. Como você vê o construtivismo? Quais são os prós e contras?

Fernando Ferreira: Olha, eu acho que o grande projeto pedagógico é: o aluno ter cinco refeições por dia, morar numa casa que tenha condições mínimas para ele viver, que ele tenha uma família estruturada - no sentido de uma família que dê respaldo afetivo para aquela criança. Mas eu não acho que isso seja a salvação da lavoura do negócio, eu acho que, pelo contrário, justamente como eu falei, acredito que o principal problema da educação não se encontra no modelo pedagógico adotado, mas se encontra nas condições materiais para esse processo efetivamente acontecer. Então, é claro que entre o construtivismo ou uma perspectiva mais conteudista, eu prefiro o construtivismo. Agora, não acho que isso seja, como eu disse para vocês, a salvação da lavoura.

Revista Epígrafe: Você poderia falar um pouco para gente como foi as suas outras experiências na educação? Que saíam um pouco do modelo da Escola da Vila...

Fernando Ferreira: Eu trabalhei também com educação não formal para adultos. Eu acho que é uma experiência fundamental para quem quer dar aula. Porque você se depara com grupos heterogêneos, que trazem formações muito distintas, têm interesses muito distintos em torno daquilo que você está oferecendo. Eu tive uma experiência fundamental com idosos. Era um curso que era oferecido pela Secretaria dos Direitos Humanos da prefeitura de São Paulo, e a ideia era a seguinte: você tem uma mobilização gigante de idosos na cidade, uma atividade política muito forte de idosos, principalmente nos conselhos de hospitais, nos conselhos de saúde, 


\section{entrevista}

A prática da educação construtivista

associações de moradores, etc. E aí, um grupo lá da Secretaria, conhecendo essa atuação dos idosos, procurou criar um curso de formação política, um curso que desse conta de discutir questões de saúde do idoso em uma perspectiva social, histórica e política. Pensando na sua atuação política, enfim, no estudo e na defesa do Estatuto do Idoso. Agora que ganhou uma importância enorme, o BPC [Benefício de Prestação Continuada], na reforma da previdência, e que muita gente nem sabia que existia. Então foi bem interessante isso, de formular algo que foge do currículo, pensar esse tipo de educação, em que você vai dar uma formação política. Ela não tem preocupação com a disciplina da obrigação escolar, da educação curricular. Mas sim com essa perspectiva de construção de um sujeito político. Pessoas que, muitas vezes, têm uma concepção política muito diferente daquilo que está tentando ser construído, né? Você lidando com essas tensões dentro desse ambiente de estudo e, principalmente, o que você aprende com essas pessoas também. Da mesma forma que você aprende com a molecada, experimentando uma sala de aula com trezentas crianças ali, inevitavelmente você acaba tendo que refletir sobre uma série de coisas que nunca tinham passado na sua cabeça. Isso também ocorre e de maneira bem intensa em um ambiente com pessoas mais velhas, com vivências muito particulares, questões políticas muito particulares. E conseguir mediar isso é muito desafiador e muito bacana.

Revista Epígrafe: E nessas suas experiências, você adotou uma postura mais construtivista ou isso não estava em jogo, não era uma questão ali?

Fernando Ferreira: Eu acho que a perspectiva construtivista, de que o indivíduo é o principal sujeito da construção do conhecimento, hoje é quase hegemônica em todas as correntes pedagógicas, chegando a ter até algumas formas de apropriação do 


\section{entrevista}

Fernando Sarti Ferreira

construtivismo um pouco perigosas, como por exemplo o casamento do construtivismo com o neoliberalismo, né? Dessa completa auto-responsabilização pelo processo de aprendizagem que quase não precisa mais de mediação, só de "facilitadores". O indivíduo constrói o seu conhecimento, mas com a mediação, enfim, do grupo e do agente cultural, que é o professor. Contudo, acho que a importância dos conhecimentos prévios para elaboração da didática é um aspecto de validade universal do construtivismo, independente de se estar em um ambiente formal ou não formal. Lembro, por exemplo, nesse curso com idosos, quando a gente discutiu o processo de modernização econômica a partir da década de 50, a riqueza que era trabalhar a partir de perguntas como: “como é que você veio parar em São Paulo?", “como é que a sua família veio parar aqui?". E aí, a partir dessas experiências de vida, você ia puxando ali “olha, esse aqui é o processo de modernização econômica, êxodo rural, formação das periferias nas grandes cidades, etc.".

Revista Epígrafe: Como é a sua adaptação para as aulas dos alunos depois de dar aulas para a terceira idade? Quais são as diferenças de abordagem que você tem que ter para cada um dos públicos?

Fernando Ferreira: Quando você está com um cara na escola, há uma série de outras coisas que você precisa avaliar e que na educação não formal você não tem, ou que só estão ali de maneira acessória, né? Claro que, por exemplo, em muitas situações de educação não formal, você pensa em uma atividade ou em uma situação que vai exigir o trabalho com escrita, mas muitas vezes você chega em um público que tem muita gente que não sabe escrever. Então, o que você faz ali? Você adapta, então, e vai pensando em uma alternativa. Nesse sentido é muito menos rígido, apesar de ser muito mais desafiador. Agora, educação escolar é aquela coisa. Você tem ali uma 


\section{entrevista}

A prática da educação construtivista

série de procedimentos que tem de ser cumprida... Eu acho que essa é a grande diferença, a escola é muito mais amarrada, ela é muito mais engessada, e eu não sei se tem uma outra forma de ser escola se não for assim. Enquanto na educação não formal o objetivo é a construção de outra coisa. Então a escola tem esse lado disciplinador mesmo, repressivo e engessado, não tem jeito [risos].

Revista Epígrafe: Aproveitando essa ideia de que a escola é um ambiente engessado, você podia ajudar a gente a pensar um pouco como é seu cotidiano de trabalho dentro de uma escola particular?

Fernando Ferreira: É como eu falei, a escola em que eu trabalho tem uma vantagem, digamos, de ter um ambiente escolar muito bem consolidado. São alunos também que têm condições materiais que garantem ali que as coisas aconteçam de maneira bem mais simples do que em outras situações. Agora, do ponto de vista de cotidiano de trabalho, é lógico também que eu estou falando de uma situação que é privilegiada, mas que não está imune a uma série de processos que são comuns para toda a categoria. Há uma questão do sobretrabalho que está cada vez maior para os professores, em relação a uma série de tarefas burocráticas, de preenchimento de coisas. Isso tem tomado cada vez mais tempo do professor. Agora com essa coisa de EAD [Ensino à distância], essa informatização da escola permite o aparecimento de uma série de mecanismos de controle, tanto da jornada de trabalho do professor, quanto do conteúdo discutido pelo professor, como a questão do Escola sem Partido. Se eu estou no EAD, eu posso ter um aluno gravando essa conversa, eu posso ter um aluno sentado com o pai aqui conferindo se o cara está chamando ditadura de ditadura ou não. Enfim, a escola sabe que horário você entrou, que horário colocou, quanto tempo usou tal plataforma ou não. Claro, com distintos graus e com as 


\section{entrevista}

Fernando Sarti Ferreira

especificidades aí desse mundo heterogêneo que é o mundo da educação, mas é uma tendência geral, esse controle maior, acompanhado da precarização do trabalho. Uma precarização em que sentido? Cada vez mais trabalho, mais controle sobre seu trabalho, mais exigências. Por exemplo, agora todo mundo tem essa coisa do "ah, pensar por projetos e projetos individualizados, itinerário pessoal do aluno". Você está criando uma individualização no atendimento, uma individualização na observação da trajetória do aluno que é uma loucura de trabalho. Com isso, você anula uma das poucas coisas que existem de bom na escola, que é essa convivência coletiva, esse espaço coletivo de relação e de construção de conhecimento. Então, eu vejo, nesses dez anos que eu estou trabalhando na educação básica, que há um acelerado processo de precarização. É óbvio que em graus muito distintos, em velocidades muito distintas, com várias peculiaridades, mas a coisa tem ficado pesada para o professor.

Revista Epígrafe: Aproveitando ainda essa sua fala, em tempos de coronavírus, como é ensinar História?

Fernando Ferreira: Tem essa coisa que eu estou me adaptando também aqui ao Google Meets, ao EAD. É uma coisa muito esquisita. Eu estou no Ensino Médio, então, de certa forma, a minha situação está um pouco mais confortável também de trabalhar, porque os meus alunos têm um pouco mais de autonomia. Eu posso fazer um curso como é dado na faculdade: eles leem um texto, a gente abre isso aqui [Google Meets] e discute o texto. E aí sem contar essa coisa do EAD terrível... Hoje eu li um documento, por exemplo, dos professores da Diretoria Regional de Ensino da rede municipal do Campo Limpo fazendo questionamentos ao EAD no Ensino Municipal, que é isso, se parte do pressuposto que toda juventude e famílias têm 


\section{entrevista}

A prática da educação construtivista

acesso a computadores e à internet para fazer a coisa... É uma loucura isso que esteja rolando. Terrível, terrível, não tem por onde descrever, mas a pandemia exacerba todas essas contradições que permeiam a nossa sociedade. As pessoas estão vivendo esse momento histórico; o escancaramento da desigualdade sociedade brasileira não tem por onde, né... E isso permeia toda nossa história. Fica claro agora algo que podia estar mais ou menos mascarado por uma vida um pouco alienada, agora está na cara, não tem por onde escapar disso.

Revista Epígrafe: E para as suas aulas, Fernando, como é que você monta o currículo escolar? É baseado na BNCC [Base Nacional Comum Curricular]? Como você seleciona seus temas de aula?

Fernando Ferreira: Então, eu entrei na escola e já havia um currículo estabelecido que tem relação com a BNCC. Na verdade, a BNCC é muito aberta. Depois dessa última versão, ainda continuou aberta, muito aberta. Então, a gente vai encaixando, procura dar o encaixe na BNCC dentro de um currículo que já existia na escola. Esse currículo existia na escola antes de eu entrar. E currículo é aquela coisa, as pessoas criam e depois ninguém lembra mais quem fez, nem o porquê. Fica lá. Então, de certa forma a gente vai tentando adequar à BNCC, mas a gente não segue rigidamente. Porque, na verdade, em grande medida, quem determina o currículo, principalmente nas escolas particulares, é a FUVEST [Fundação Universitária para o Vestibular], mais que a BNCC. Agora, o ENEM [Exame Nacional do Ensino Médio] ganhou importância nas escolas também em decorrência do SISU [Sistema de Seleção Unificada]. Acho que, até pensando na reforma do ensino médio, a coisa só vai engrenar mesmo quando isso se adequar às provas dos vestibulares. Então é sempre essa tensão no currículo. Também não tem que ter uma ilusão de que o professor vai dar o currículo inteiro, 


\section{entrevista}

Fernando Sarti Ferreira

tem a ver com as suas opções, tem a ver com a questão de você ter que ensinar História. Como é que você ensina melhor História? Eu acho que essa é uma questão que tem que ser pensada quando você tem um currículo tão amplo. Eu acredito que o melhor seria o próprio professor ter a liberdade de fazer isso. Mas sempre haverá essa tensão, porque tem uma base comum de um lado e do outro tem essas provas de vestibular.

Revista Epígrafe: Mas nessa tensão do currículo que você falou, você consegue encaixar alguns temas que Ihe são caros? Acho que a gente sempre tenta fazer isso de alguma maneira, dependendo do nosso viés político e tudo mais, a gente sempre tenta encaixar algum tema que é caro para gente.

Fernando Ferreira: É, a tensão tem ficado cada vez maior na verdade. Até porque o que aparece de gente querendo falar o que é História... A gente tem sido substituído por YouTubers e gente meio estranha. E aí, na escola particular, isso é pior, porque a pressão do pai é a pressão do cliente. Apesar de eu ainda estar inserido numa comunidade escolar que é bem, bem privilegiada, apesar de estar sofrendo cada vez mais essa pressão, porque é o seguinte... É claro que, a escola particular serve à classe média; e, é claro, a classe média, no geral, nos últimos dez anos, deu um giro generalizado para a extrema direita. Nos últimos anos, a gente teve que abandonar, por exemplo, um trabalho de campo que ia para o MST [Movimento dos Trabalhadores Sem Terra], porque era muita "encheção de saco", era muito questionamento. Mas eu acho que a melhor forma de você driblar isso, é se proteger na História, na historiografia, na ciência e no que é produzido. Esse é o grande trunfo que você tem. Apesar de que muitas vezes não vai adiantar, em certas situações. Mas essa situação já chegou a um ponto tão irracional que, eu sei lá se a discussão é 


\section{entrevista}

A prática da educação construtivista escolar ou pedagógica, já é outra coisa, já é perseguição política, já é fascismo. Mas eu acho que enquanto há um respiro em alguns ambientes, nos quais ainda há uma possibilidade de uma atuação um pouco mais tranquila, eu acho que a questão se aferra ao seu campo, se aferra à História, ao que é produzido, à historiografia; isso é uma grande arma. Claro, nesses ambientes em que a coisa já não degringolou para o fascismo diretamente, para uma coisa louca.

Revista Epígrafe: Isso é curioso, pois historicamente o ensino construtivista é associado à esquerda, e mesmo em uma escola construtivista isso está sendo questionado, em tempos em que o Paulo Freire é diariamente massacrado... É muito curioso isso, uma pessoa procurar uma escola construtivista, e ao mesmo tempo bater de frente com um tipo de ensino que é assim.

Fernando Ferreira: O Gramsci, fazendo uma análise da Itália fascista, tem uma colocação que é muito interessante e que explica um pouco isso. Ele fala o seguinte: “Olha, a consciência das pessoas, ela é fragmentada. Totalmente fragmentada. Essa coerência [risos], isso é coisa de intelectual, de militante político, entendeu? No geral, é essa coisa fragmentada." Então, na verdade, assim,... Uma coisa bem impressionista que eu vou falar para, mas que tem a ver com essa consciência um tanto fragmentada. Você observa isso ao longo da vida escolar das crianças e do comportamento desses pais e clientes de classe média. O construtivismo é lindo no[ensino] fundamental I. Ah, a criança vai se desenvolver, vai criar autonomia... Quando essa autonomia começa a virar uma autonomia intelectual mais consistente, e ele passa, de certa forma, a enfrentar os pais, isso vira um problema. Aí o cara começa a reclamar da doutrinação. Não, o seu filho está virando uma pessoa independente, está virando um adolescente, então ele está passando por esse 


\section{entrevista}

Fernando Sarti Ferreira

processo de ruptura, e que, no caso, aqui, isso está se traduzindo em uma outra percepção de mundo que ele está tendo. Então é isso... E aí tem um caso pior ainda, que é o cara que quer construtivismo para o filho dele e, para os pobres, ele quer colégio militar. Isso acontece também. Acha que o construtivismo é lindo, essa coisa do autodesenvolvimento da criança, a autoconstrução da criança, mas da minha criança. Para os pobres, é colégio militar, é Escola Sem Partido. Então, eu acho que, assim, também não dá para fazer essa associação entre construtivismo e esquerda. Veja só, a escola na qual eu trabalho, que é uma referência no construtivismo, ela foi comprada por um grupo empresarial, um grupo de investimentos liderado por conservadores. E não é só a minha escola, ela está comprando muitas escolas que são referência no Brasil inteiro em construtivismo. E não estou entrando nem no mérito de julgar os caras politicamente. Talvez se associe a posturas mais progressistas pelo momento histórico que essas escolas surgem, porque essas escolas têm, digamos, uma primavera durante o processo de abertura política e redemocratização... É possível identificar, então, o processo de abertura à implementação dessas práticas, porque, de certa forma, se a gente pegar o DNA desse construtivismo brasileiro, é um projeto que foi interrompido em 1964. Um dos projetos que estava em disputa era uma nova forma de educação que tinha o Paulo Freire como a grande figura. E que depois vai ser retomado por essas escolas a partir do final dos anos 1970 e 1980. Então, eu acho que a ideia dessa coisa de "Ah, ficou próximo à esquerda" tem muito mais a ver com esse contexto, né? E talvez hoje, com essa loucura que a gente vive, pode até ser percebida como uma coisa à esquerda, mas não é uma coisa comprometida com um processo de transformação social radical da sociedade. É uma perspectiva humanista de educação, muito mais humanista do que tecnicista e utilitarista, digamos assim; e que, como teve essa primavera no processo de redemocratização, talvez tenha ficado associada a isso, 


\section{entrevista}

A prática da educação construtivista

mas hoje é um grande negócio.

Revista Epígrafe: Uma coisa que você falou é sobre a apostila. O padrão da escola particular geralmente é o ensino apostilado. Como isso se encaixa na realidade do professor, ter que lidar com a apostila, ter que utilizar a apostila, como uma pressão da escola, dos pais, dos alunos?

Fernando Ferreira: O sistema apostilado também acaba virando uma espécie de controle do trabalho. No sistema público também tem avançado, principalmente em decorrência das provas do SARESP [Sistema de Avaliação do Rendimento Escolar do Estado de São Paulo]. Isso aí você engessa o currículo. Por exemplo, você está com uma sala - isso acontece em muitas situações - você está lá na sala, ocorre sei lá, uma situação de machismo, racismo ou homofobia na sala. Quando você está com os adolescentes é uma ótima oportunidade de falar “não, pera aí, galera, vamos discutir isso aqui, vamos entender isso aqui", você gasta um tempo para que daquela situação você tire um aprendizado significativo, relacionando com História, relacionando com sei lá o quê você estiver ensinando. É dessa vivência que surgem os aprendizados mais significativos, de você conseguir transformar aqueles conflitos que você tem, aqueles problemas que surgem ali numa sala, numa discussão, numa questão, que os adolescentes consigam pensar naquilo e formular aquilo e resolver aquilo. Num programa apostilado, o que você tem? Você tem metas - é isso que você tem - a serem atingidas. E metas que são controladas por pessoas que estão completamente alheias à situação de aula. Elas não estão se importando se você tem lá uma situação que você queria trabalhar com os seus alunos para discutir melhor. O que importa é o quê? Que em tal semana você tenha chegado em tal matéria. Até porque em muitos desses sistemas apostilados as provas têm vindo de fora. O professor não consegue 


\section{entrevista}

Fernando Sarti Ferreira

nem mais hierarquizar e selecionar o que é que ele quer avaliar dos seus alunos. Porque isso é uma coisa que acontece... O planejamento de aula que você faz é para dar errado, completamente errado; ele dá errado e é para ele dar errado. É uma loucura você querer dobrar os alunos para eles entrarem no seu planejamento, isso é uma loucura. O planejamento é mais ou menos como uma boia que você vai flutuando nessa coisa maluca que é estar na sala de aula com os moleques. É como eu falei, pode acontecer uma situação grave, de machismo, racismo ou homofobia, pode acontecer uma coisa muito legal, que eles chegam ali a um problema e a um tema que é muito interessante e você fala "não, vamos aprofundar isso aqui, eu vou por aqui", e você faz esse replanejamento em decorrência dessa dinâmica que você vai tendo em sala de aula. O problema desse sistema apostilado é que ele engessa, ele acaba com isso e ele cria um controle externo. Você é um mero aplicador daquilo ali. E se você sair disso aqui, não interessa se a aprendizagem é significativa ou não, o que interessa é o ponto no SARESP, é o ponto lá no simulado, e é isso que vai te pontuando ou não como professor. "Ah, você está sendo um bom professor, ou um mau professor", é isso que vai te definindo. Então o sistema apostilado é um outro sistema de controle. Com esse controle externo da sala de aula que, enfim, aborta toda a potencialidade que você tem em uma sala de aula, que é justamente trabalhar em cima desses conflitos, em cima dessa confusão, né?

Revista Epígrafe: E, Fernando, que competências você acha que o professor deve ter para esse cotidiano?

Fernando Ferreira: Olha, você vira professor na sala; a sala te faz professor; os tímidos deixam de ser tímidos. Eu não sei se tem tantas competências, porque há vários tipos de professor nas escolas, isso é interessante também. Você pode falar: "Ah, eu sou 


\section{entrevista}

A prática da educação construtivista

uma pessoa muito, muito afetuosa". Eu conheço grandes professores muito afetuosos. "Ah, eu sou uma pessoa mais fria." Eu conheço professores maravilhosos que são frios, que são distantes, são mais rígidos... Então, eu acho que a sala de aula é um lugar de pluralidade, tanto por parte dos alunos, como por parte dos professores também. São vários os professores possíveis, né? Você mesmo, ao longo da sua carreira, vive vários professores. Isso muda também, com a sua percepção de sala de aula, com o tempo que você vai passar na escola, isso acaba te modificando também. Então eu não acho que exista alguma característica pré-determinada que facilite o ofício... Eu acho que é isso, são várias as possibilidades de ser professor. O importante é você ter o quê? Condições materiais, e que as crianças também tenham condições materiais, esse é o grande nó da coisa. A escola não vai salvar a sociedade, é a sociedade que tem que salvar a escola. Essa é a questão.

Revista Epígrafe: Você chegou a dar aula para ensino fundamental II também, né? Como é dar aulas para faixas etárias tão diferentes, lembrando de suas outras experiências com ensino de idosos no pré-vestibular, como é dar aula para essa gama tão diversa de gente e de idades?

Fernando Ferreira: Eu acho que isso também é outra coisa que você vai se identificando quando você está dando aula. Você vai se apegando a uma faixa etária quando você tem a possibilidade de fazer isso. A maior parte dos professores não têm, eles têm que pegar a aula que tem. É esse tipo de determinação, que é dado pela possibilidade de vagas disponíveis numa escola ou uma imposição do patrão, que vai falar "olha, você pega essa aula ou você está fora". Eu acho que ter vivido diversas faixas etárias foi maravilhoso, apesar de eu me identificar muito mais agora com os anos finais, ensino médio. Mas eu acho que para aprender a dar aula, o 


\section{entrevista}

Fernando Sarti Ferreira

fundamental II, digamos, foi fundamental. Para você pensar a didática, para entender o que é uma transposição didática, pegar aquele conhecimento que é produzido na universidade e tentar trazer isso para os moleques, treinar procedimentos fundamentais. Então, você pega um cara de FII [ensino fundamental II], você tem que fazer o cara aprender a ler. Você senta com o cara e fala "olha, vamos ler um texto de História, isso é um aprendizado, uma alfabetização em História". Isso é muito bacana. Pelo menos para mim, foi bem formativo como professor poder acompanhar de perto esses processos bem incipientes, como você vai construindo com a molecada. Mas hoje, não sei, eu acho que até por ter mais essa ideia da pesquisa de História, eu acho que eu gosto mais de discutir com a molecada do ensino médio. O Fll, enfim, é uma experiência fundamental, foi maravilhoso, para aprender a ser professor. E é isso, cai do pré-vestibular para o Fll diretamente. O pré-vestibular você entra e fala e não tem que acompanhar os moleques. Enfim, tem as demandas do corpo dessas crianças, também, que estão adolescendo, que já é outro tema, o barulho [risos] que é... Depois que você deu aula para um sexto ano, gente, você dá aula para um poste [risos].

Revista Epígrafe: Que dicas você daria para um estudante de História que quer ser professor nos dias de hoje?

Fernando Ferreira: Difícil, hein? [risos] Eu acho que é isso, experimente tudo: todas as faixas etárias, todas as possibilidades de trabalhar com educação; vai para o cursinho popular; vai para a escola; vai para o ensino fundamental II; vai dar aula em biblioteca pública; monta oficina; experimenta de tudo, quanto mais experiências você vivenciar, melhor. Quanto mais tipos de vivência melhor. 